\title{
IDENTIFICATION OF Acacia mangium PROVENANCES FOR SOLID-WOOD FOREST PLANTATIONS
}

\author{
Nurhasybi ${ }^{1,2}$, Dede J. Sudrajat ${ }^{1}$, and Komar Diatna ${ }^{3}$
}

\begin{abstract}
Provenance trial is a planting test aimed at finding the best provenance for establishing forest plantations. Such best provenance depends on the type of final harvest or yield expected. The objective of this research was to identify $A$. mangium provenances that were suitable for forest plantation producing solid woods for construction and furniture. A total of 225 samples of 15 provenances from Papua New Guinea and Australia were planted in three blocks in Parungpanjang, Bogor, West Java. The measured parameters included tree height, clear bole height, stem diameter, tree volume, stem form, branching habit, and crown form. Bi-plot analysis indicated that Kini WP, Keru Village WP, Derideri R. Morehead, and Claudia River were the best provenances in terms of productivity. Correspondence analysis showed that almost all provenances were equally good in stem form, but they varied in branching system as well as crown form. Provenances Kini WP, Keru Village WP, Kiriwo/Serisa WP, and Bimadebun Village possessed the better branching habit. In terms of crown form provenances Dimisi Village WP, Kiriwo/Serisa WP, and Derideri R. Morehead exhibited a good performance. In general, five provenances, i.e. Kini WP, Keru Village WP, Derideri R. Morehead, Kiriwo/Serisa WP, and Claudia River were considered appropriate for seed sources supplying seeds for industrial plantation development intended to produce construction and furniture material.
\end{abstract}

Keywords: Bi-plot, correspondence, seed sources, industrial plantation

\section{INTRODUCTION}

Acacia mangium is a fast growing tree species naturally distributed across Northeastern Australia, Papua New Guinea and Irian Jaya. It naturally occurs along the boundary of the tropical warm and hot climatic zones, and either humid and wet at altitudes below $50 \mathrm{~m}$. A. mangium occurs on a wide range of soil types, derived from acidic parent material, rarely on basic rocks. The soil may have impeded drainage and be of low fertility. This species is found on the fringes of rain forest, open forest and woodland (Turnbull, 1982). This species has a high potential for plantation program in commercial plantation and can be adapted in marginal, stony and degraded sites colonized by Imperata cylindrica (Turnbull, 1982; Otsamo, 1996; Vuokko, 1996; Raebild et al., 2003).

Forest Tree Seed Research Institute, Jl. Ciheulet PO. Box 105 Bogor 16001, Indonesia.

Corresponding Author. E-mail: d hasybi@yahoo.com.

3 Faculty of Nature Science and Mathematics, Bogor Agricultural University, Kampus IPB

Darmaga, Bogor 16680, Indonesia. 
In Indonesia, A. mangium was introduced the first time to Subanjeriji-South Sumatra in 1970s. Genetic material was obtained from 4 provenances of South Queensland, Australia. In several species trials and pilot plantations, A. mangium has proved to be the most promising and reliable tree species for plantation. On grassland area, $A$. mangium was also proven to be superior. This species has reached a mean annual increment of more than $40 \mathrm{~m}^{3} \mathrm{ha}^{-1} \mathrm{yr}^{-1}$ on several sites (Palokangas, 1996). Its good adaptability on almost all site places makes $A$. mangium as the largest species developed in Industrial Timber Estates (HTI). From a total of around 2.5 million ha of the plantations, over 1 million hectare have been established for $A$. mangium (Arisman and Hardiyanto, 2006).

In 1990s, to increase the genetic variation of $A$. mangium, Ministry of Forestry of Indonesia in cooperation with the Commonwealth Scientific and Industrial Research Organization (CSIRO) Australia obtained some provenances from Queensland, Australia and Papua New Guinea (PNG). Forestry Research and Development Agency (FORDA) distributed the provenances to some research institutions (state and private) in Java, Sumatra, and Kalimantan. The provenance trial had been established in several locations, including Riam Kiwa and Pleihari (South Kalimantan), Kutai, Berau and Kenangan (East Kalimantan), Sanggau (West Kalimantan), Tanjung Jabung (Jambi), Selutung, Muara Enim and Ogan Komerin Ulu (South Sumatra), Pidie (Aceh), Cirebon and Bogor (West Java), and Indah Kiat (Riau) (Zanzibar et al., 1997). Some evaluations on A. mangium provenance trial were carried out to assess the provenance matching with site (Suhaendi, 1993; Voukko, 1996; Sugama and Sutiono, 1999; Hardiyanto et al., 2000; Zanzibar, 2001). Almost all of the studies intended to identify the best provenances for pulp and paper materials.

Indeed $A$. mangium has been known an excellent raw material for pulp and paper production. The fiber length $(0.7-1.0 \mathrm{~mm})$, coarseness $\left(0.7 \mathrm{mg} \mathrm{m}^{-1}\right)$, fiber wall thickness $(3.0-4.5 \mu \mathrm{m})$, lignin content $(30 \%)$ and easiness to cook are the characteristics of wood required to be excellent for pulp and paper raw materials (Palokangas, 1996). But in recent years, A. mangium also contributes significantly to the forest industry beyond pulp and paper in Indonesia (Rimbawanto, 2002). Indeed, when free from defects, the wood looks quite similar to teak (Gales, 2002). In Java, this species is also developed in the small-scale plantations.

In this research, identification of $A$. mangium provenance is meant to select the best provenances for seed source establishment to support plantation programs intended to produce construction and furniture materials. Bi-plot and correspondence analyses were used for that purpose. 


\section{MATERIALS AND METHODS}

\section{A. Site}

This study was conducted at Parungpanjang Forest Research Station (lat. $106^{\circ}$ $6^{6}$, long. $106^{\circ} 20^{\circ}$ ) Bogor, West Java (Figure 1). The altitude of the site is $51 \mathrm{~m}$ above sea level. Soil type is haplic podsol with a $\mathrm{pH}$ of 4.8. The soil fertility organic matter, Phosphor, and Kalium contents are low. The climate falls into type A according to Schmidt and Ferguson classification, with an annual rainfall between 2000 and $2500 \mathrm{~mm}$ (dry season 6-8 months per year) (Sudrajat et al., 2006). The original vegetation on the site was dominated by Imperata cylindrica grassland and Schima wallichii coppices before converted to A. mangium provenance trial in 1995.

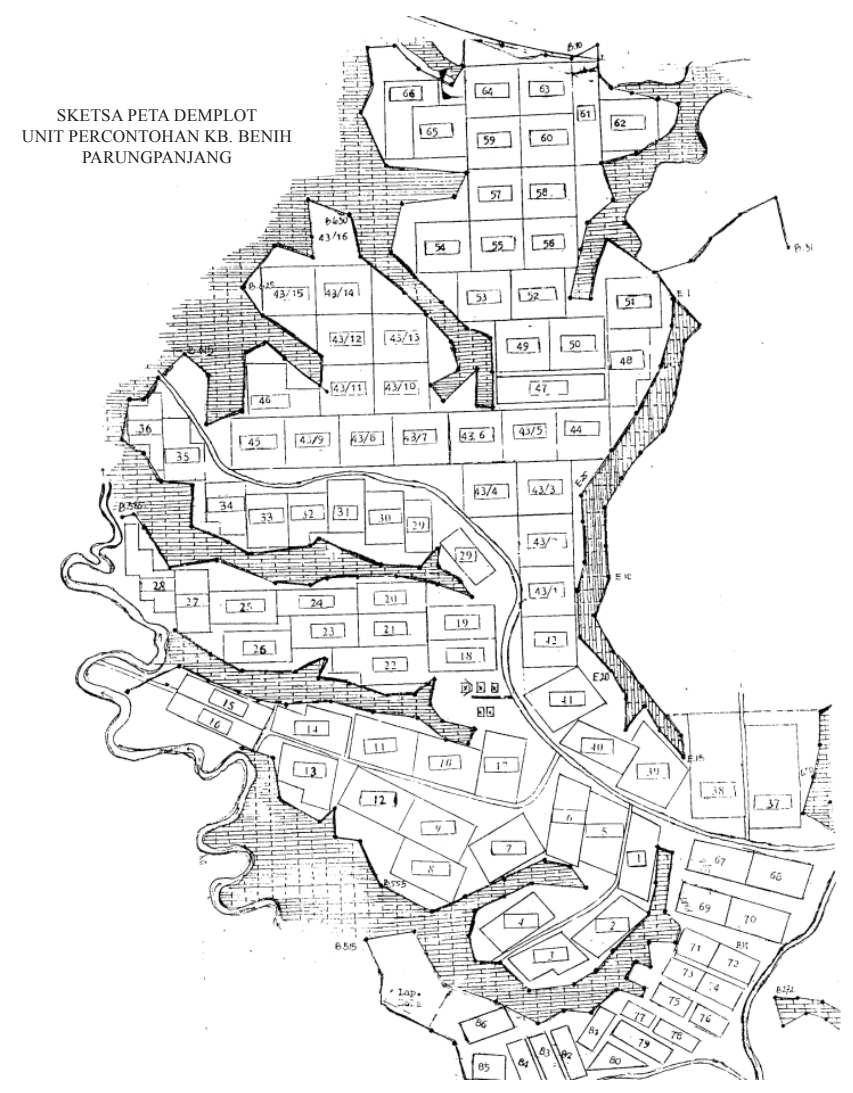

Figure 1. Acacia mangium provenance trial location in Parungpanjang Forest Research Station 


\section{B. Experimental Design}

The $A$. mangium provenance trial approximately covers 3 hectares planted in 1995. Table 1 presents the list of $15 \mathrm{~A}$. mangium provenances from Queensland, Australia and Papua New Guinea (PNG) planted in a randomized complete block design with three blocks. In each block, provenance was represented by one plot of 40 trees. The spacing was $3 \mathrm{~m} \times 3 \mathrm{~m}$. In every provenance five trees were sampled randomly resulting in a total of 75 trees in each block representing every provenance. With three blocks, in total the sample trees were 225 trees.

\section{Table 1. List of $A$. mangium provenances}

\begin{tabular}{clccc}
\hline $\begin{array}{c}\text { Provenance } \\
\text { code }\end{array}$ & \multicolumn{1}{c}{ Origin of provenances } & Latitude & Longitude & $\begin{array}{c}\text { Altitude } \\
(\mathrm{m})\end{array}$ \\
\hline 16937 & Balimo District, PNG & $8^{\circ} 17^{\circ}$ & $143^{\circ} 6^{\prime}$ & 30 \\
16938 & Kini WP, PNG & $8^{\circ} 5^{\circ}$ & $142^{\circ} 58^{\prime}$ & 12 \\
1699 & Derideri R. Morehead, PNG & $8^{\circ} 42^{\circ}$ & $143^{\circ} 6^{\prime}$ & 30 \\
17703 & Tully Mission Beach, & $17^{\circ} 55^{\circ}$ & $146^{\circ} 5^{\prime}$ & 20 \\
17820 & Queensland & $8^{\circ} 1^{\circ}$ & $142^{\circ} 41^{\prime}$ & 10 \\
17866 & Aramia R. Balimo WP, PNG & $6^{\circ} 51^{\circ}$ & $141^{\circ} 29^{\prime}$ & 55 \\
17945 & Lake Murray, PNG & $12^{\circ} 14^{\circ}$ & $142^{\circ} 54^{\prime}$ & 20 \\
17946 & Olive River, Queensland & $21^{\circ} 48^{\circ}$ & $143^{\circ} 18^{\prime}$ & 20 \\
18057 & Claudia River, Queensland & $8^{\circ} 52^{\circ}$ & $143^{\circ} 5^{\prime}$ & 30 \\
18201 & Kuru, PNG & $8^{\circ} 31^{\circ}$ & $142^{\circ} 13^{\prime}$ & 50 \\
18204 & Dimisi Village WP, PNG & $8^{\circ} 38^{\circ}$ & $142^{\circ} 3$ & 40 \\
18206 & Bimadebun Village, PNG & $8^{\circ} 43^{\circ}$ & $141^{\circ} 55^{\prime}$ & 25 \\
18208 & Arufi Village, PNG & $8^{\circ} 36^{\circ}$ & $141^{\circ} 45^{\prime}$ & 25 \\
18209 & Keru Village WP, PNG & $8^{\circ} 25^{\circ}$ & $141^{\circ} 30^{\prime}$ & 45 \\
18212 & Kiriwo/Serisa WP, PNG & $8^{\circ} 53^{\circ}$ & $141^{\circ} 17^{\prime}$ & 25 \\
& Bensbach Area WP, PNG & & & \\
\hline
\end{tabular}

Source: Australia Tree Seed Centre, CSIRO Division of Forestry (File no. DA1/145)

\section{Measurement}

All sampled trees were measured for their total tree height, clear bole height, stem diameter at breast height, tree volume, stem form, branching system, and crown form. The volume was measured using the following formula (Iriantono et al., 1997):

$$
V=0.00003927 d^{2} t, \quad d=\text { diameter; } t=\text { tree height }
$$

The stem form, branching system, and crown form were assessed based on the field observation on typical trees and their categories as shown in Figure 2. 


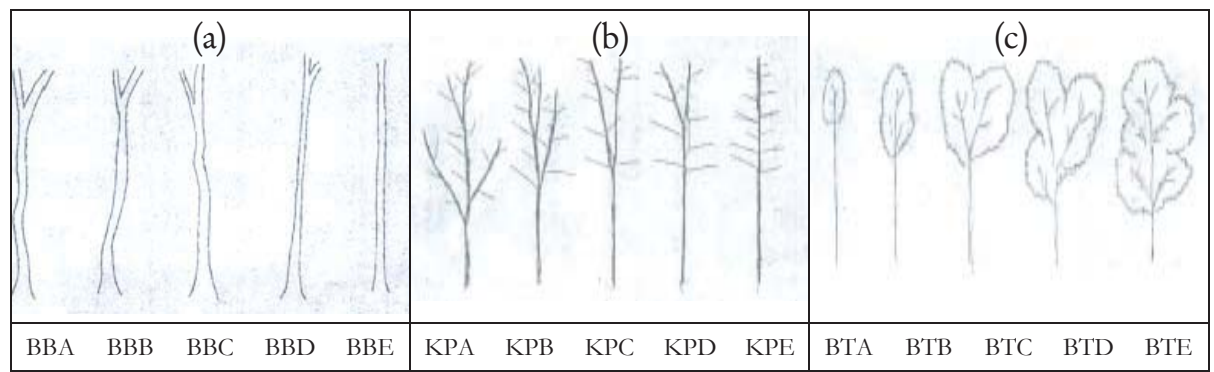

Note: $\mathrm{BBA}$ : very crooked; $\mathrm{BBB}$ : crooked and leaning; $\mathrm{BBC}$ straight, crooked begin at 5 $\mathrm{m}$; BBD: straight, but leaning; BBE: very straight; KPA: forking below $5 \mathrm{~m}$; KPB: forking above $5 \mathrm{~m}$; KPC: branches at a narrow angle, and big size at the crown base; KPD: big branches at the top of crown; KPE: small branches with wide angle; BTA: very small and this crown; BTB: small and thin crown, oval form; BTC: small crown and divided into two parts with heavy branches; BTD: big crown with heavy branches; BTE: big crown with small branches.

Figure 2. Categories of stem form (a), branching system (b), and crown form (c)

\section{Analysis}

Bi-plot analysis was used to identify the productivity of provenances (total tree height, clear bole height, stem diameter at breast height, and tree volume). This analysis estimates the correlation between observation (provenances) and the parameters (Jollife, 1986; Hadi and Sa'diyah, 2004). It is also commonly used to assess the plot relationship between species and sites (Lipkovich and Smith, 2002; Hadi and Sa'diyah, 2004). Bi-plot analysis can be done by developing a Macro that uses the built-in $\mathrm{Excel}^{\circ}$ scatter plot chart facilities to produce a bi-plot (Lipkovich and Smith, 2002). The Macro plots the row and column markers in a 2-dimensional display. Sartono (2003) stated that bi-plot that is able to show at least $70 \%$ of all information is considered quite representative. Thus, each provenance was plotted in two dimension graphics that reveal the correlation between provenances and parameters.

Correspondence analysis was used to analyze the performance of stem form, branching system, and crown form. This method is suited to analyze ordinal data. In this research, each stem form, branching system, and crown form consist of five ordinal categories. Correspondence analysis is a method that presents column and row from the data matrix (contingency table) as a dot on vector space with lower dimension (Greenacre, 1984). The data were entered as two-way array in Excel ${ }^{\circ}$. In a typical analysis, the row will correspond to the objects (provenances) and column to the parameters (Lipkovich and Smith, 2002).

The interpretation of the result in two dimensional plots is derived from the proximity of the position of each category in row and column profiles or both and 
the directions of distribution of each category in both dimensions. A close distance between two categories on the row and column profiles means that both profiles have the same distribution. Whereas, the dots (provenances) that are near to the main axis represent the average values of row or column profiles.

\section{RESULTS AND DISCUSSION}

\section{A. Productivity of Provenances}

The average tree height, clear bole height, diameter and tree volume vary, hence so do the productivity of each provenance.

Table 2. The average of tree height, clear bole height, diameter and tree volume of $A$. mangium provenances

\begin{tabular}{ccccc}
\hline $\begin{array}{c}\text { Provenances } \\
\text { code }\end{array}$ & $\begin{array}{c}\text { Tree height } \\
(\mathrm{m})\end{array}$ & $\begin{array}{c}\text { Clear bole } \\
\text { height }(\mathrm{m})\end{array}$ & $\begin{array}{c}\text { Diameter } \\
(\mathrm{cm})\end{array}$ & $\begin{array}{c}\text { Tree volume } \\
\left(\mathrm{m}^{3}\right)\end{array}$ \\
\hline 16937 & 22.00 & 14.80 & 29.11 & 0.97 \\
16938 & 22.93 & 18.60 & 26.68 & 1.04 \\
16990 & 22.53 & 15.97 & 29.16 & 1.10 \\
17703 & 20.03 & 12.50 & 30.23 & 0.88 \\
17820 & 20.07 & 14.60 & 29.19 & 0.97 \\
17866 & 20.07 & 16.03 & 26.07 & 0.85 \\
17945 & 21.27 & 14.73 & 28.25 & 0.90 \\
17946 & 21.07 & 17.43 & 27.16 & 1.06 \\
18057 & 20.33 & 15.90 & 27.01 & 0.89 \\
18201 & 20.27 & 14.80 & 28.72 & 0.92 \\
18204 & 20.87 & 17.60 & 25.97 & 0.93 \\
18206 & 21.33 & 15.80 & 27.78 & 0.94 \\
18208 & 22.37 & 17.03 & 28.23 & 1.04 \\
18209 & 20.83 & 16.43 & 28.42 & 1.02 \\
18212 & 20.60 & 16.33 & 27.95 & 1.01 \\
\hline
\end{tabular}


The result of bi-pot analysis revealed that the total variation was $90.99 \%$. The first main axis contributed to $56.21 \%$ and the second main axis contributed to $34.76 \%$ of the total variation (Table 3 ).

Table 3. Sign root and the total variation that could be explained by bi-plot

\begin{tabular}{cccc}
\hline Axis & Sign root & Proportion (\%) & $\begin{array}{c}\text { Cumulative } \\
\text { proportion (\%) }\end{array}$ \\
\hline 1 & 2.248296 & 56.21 & 56.21 \\
2 & 1.391308 & 34.78 & 90.99 \\
3 & 0.344632 & 8.62 & 99.61 \\
4 & 0.015764 & 0.39 & 100.00 \\
\hline
\end{tabular}

w 17703

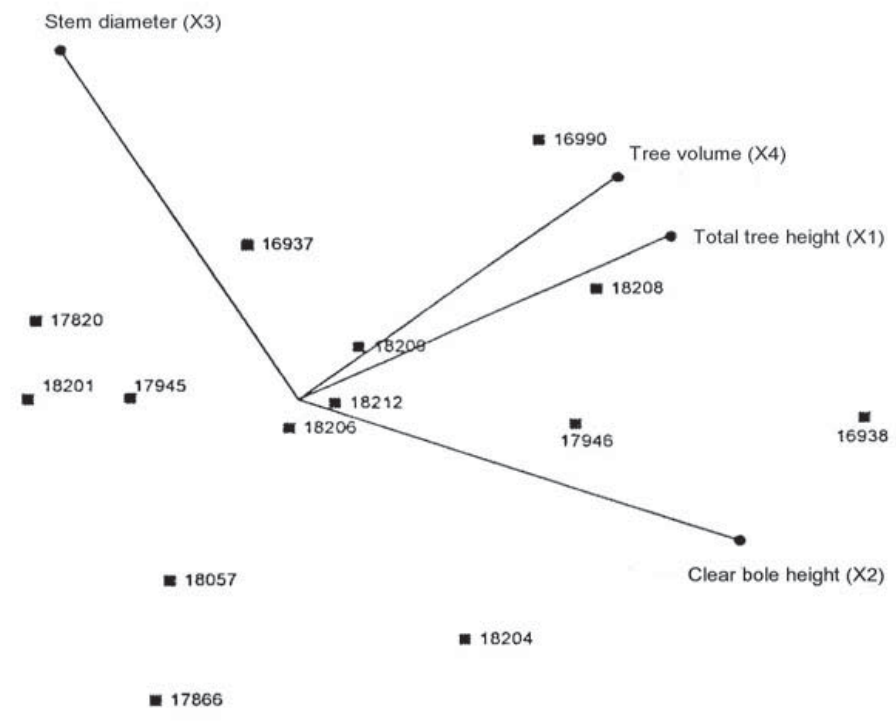

Figure 3. Bi-plot of the parameters on A. mangium provenances

As shown in the bi-plot diagram in Figure 3, tree height $\left(\mathrm{X}_{1}\right)$ and volume $\left(\mathrm{X}_{4}\right)$ form a sharp angle, indicating that the pair of parameters has a positive correlation. In other words, the taller the tree, the bigger the volume. A negative correlation is showed by the pair of clear bole height $\left(\mathrm{X}_{2}\right)$ and stem diameter $\left(\mathrm{X}_{3}\right)$ which form an obtuse angle. The negative correlation suggests a higher clear bole height is 
related to a smaller stem. Diameter-plot analysis separated the provenances into two groups. Provenance Tully Mission Beach (17703), Aramia R. Balimo (17820), Dimisi Village WP (18201), Olive River (17945), Kuru (18057), Lake Murray (17866), and Bimadebun Village (18204) formed the first group. Members of this group are laid far away from the parameters of the tree height, clear bole height, stem diameter, and tree volume, indicating that these provenances do not have the superiority on those parameters.

Provenance Arufi Village (18206), Kiriwo/Serisa WP (18209), Bensbach Area WP (18212) formed the other group. They are laid around the coordinate center, indicating that these provenances have the parameter values in the vicinity of the average. Some provenances are superior in tree height and volume, i.e. provenance Derideri R. Morehead (16990) and Keru Village WP (18208). Whereas provenance Kini WP (16938) and Claudio River (17946) are superior in tree height, clear bole height, and tree volume. Thus in general these three provenances exhibit better physical characteristic than the others. In other words, these provenances produce wood of high quality and quantity.

\section{B. Performance of Stem, Branches, and Crown}

Recapitulation of correspondence between provenances and stem form, branching system, and crown form are presented in Table 4.

Table 4. Correspondence between provenances and some parameters

\begin{tabular}{lllllrrr}
\hline \multirow{2}{*}{ Parameters } & & \multicolumn{5}{c}{ Dimension } & \multirow{2}{*}{ Total } \\
\cline { 3 - 6 } & & I & II & III & IV & \\
\hline \multirow{2}{*}{ Stem form } & Proportion (\%) & 48.90 & 28.43 & 15.53 & 6.14 & 100 \\
& Cumulative (\%) & 48.90 & 77.33 & 93.86 & 100.00 & - \\
Branching & Proportion (\%) & 46.54 & 30.97 & 14.55 & 7.94 & 100 \\
system & Cumulative (\%) & 46.54 & 77.51 & 92.06 & 100.00 & - \\
Crown & Proportion (\%) & 58.20 & 20.14 & 12.53 & 9.12 & 100 \\
& Cumulative (\%) & 58.20 & 78.34 & 90.88 & 100.00 & - \\
\hline
\end{tabular}

Based on figures in Table 4, the total of inertia (the first and second main axis) that is provided by the plot was $77.3 \%$ (stem form), $77.51 \%$ (branching system), and $78.34 \%$ (crown form). This means that the correspondence plots reveal more than $77 \%$ of the explained variation in the stem form, branching system, and crown form. 


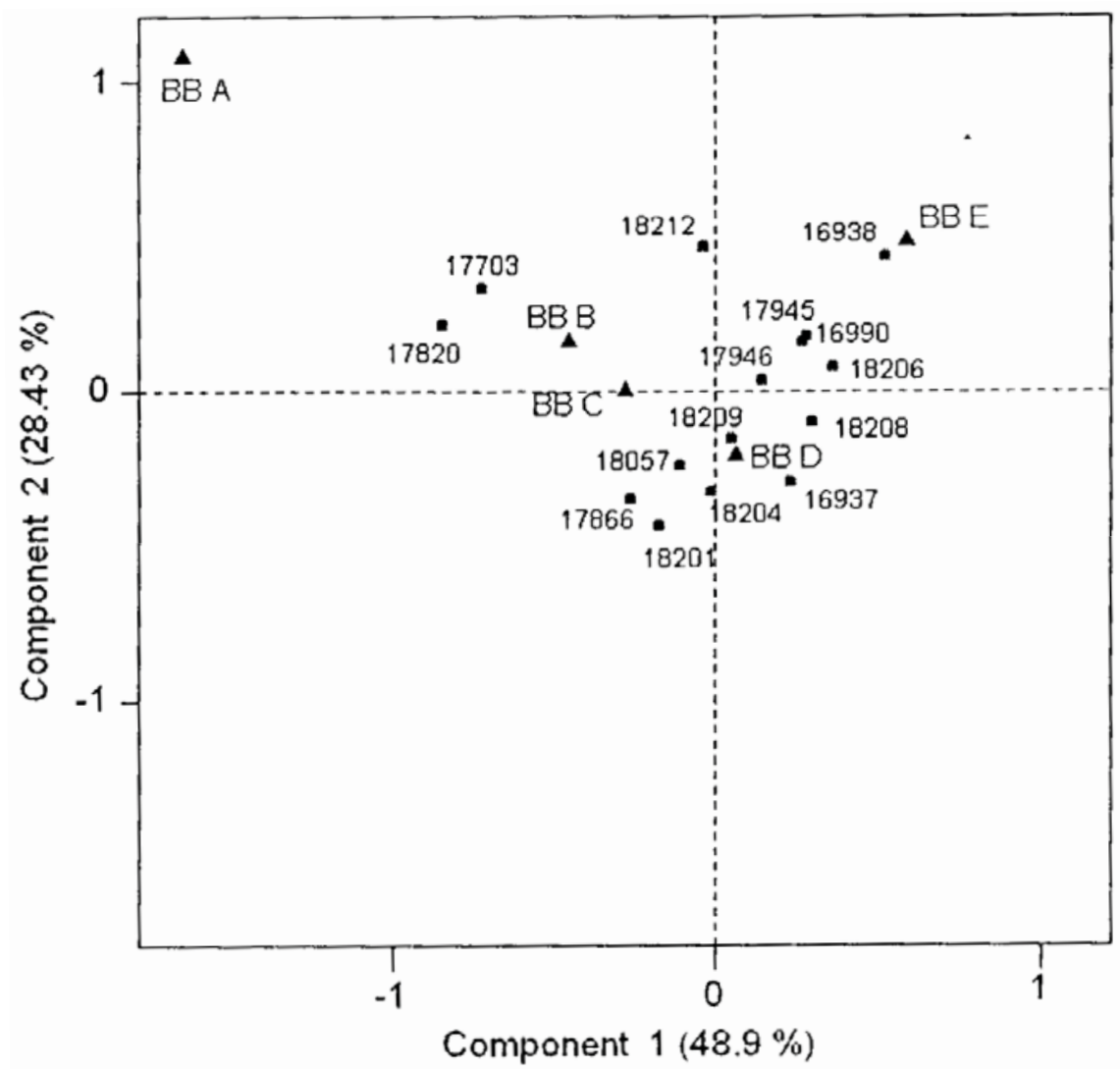

Figure 4. Plotting provenances on stem form using correspondence analysis

Referring to Figure 4, provenances appear in a cluster have the same characteristics in stem form. Most provenances are grouped around category BBD. The provenances categorized as very straight ones were Kini WP (16938), Olive River (17945), Derideri R. Morehead (16990), Arufi Village (18206), Keru Village WP (18208), Claudia River (17946), Balimo District (16937), Kiriwo/Serisa WP (18209), and Bimadebun Village (18204).

Correspondence of provenances in Figure 5 reveals that the branching system category is widely spread, although a number of provenances do cluster. Category $\mathrm{KP} \mathrm{E}$ is associated with the provenances Keru Village WP (18208), Bimadebun Village (18204), Kiriwo/Serisa WP (18209), and Kini WP (16938), and category KP D was associated with provenances: Lake Murray (17866), Bensbach Area WP (18212) and Claudia River WP (17946). Some provenances are closer to category $\mathrm{KP} \mathrm{B}, \mathrm{KP} \mathrm{A}$ and KP C which in general are associated with the poor performance of branching system. 
Journal of Forestry Research Vol. 6 No. 1, 2009:1-16

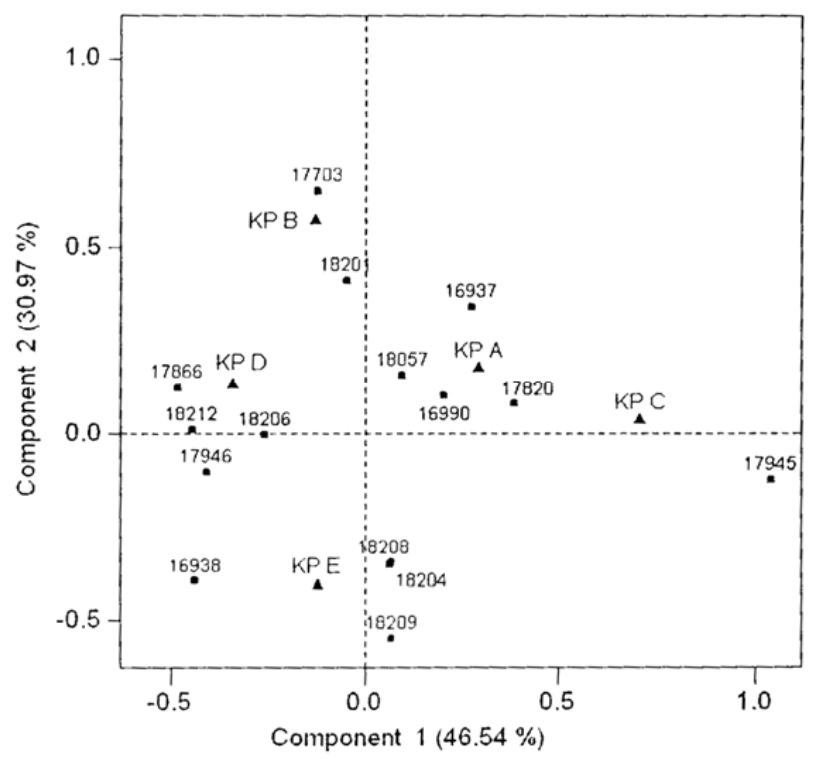

Figure 5. Plotting provenances on branching habit with the correspondence analysis

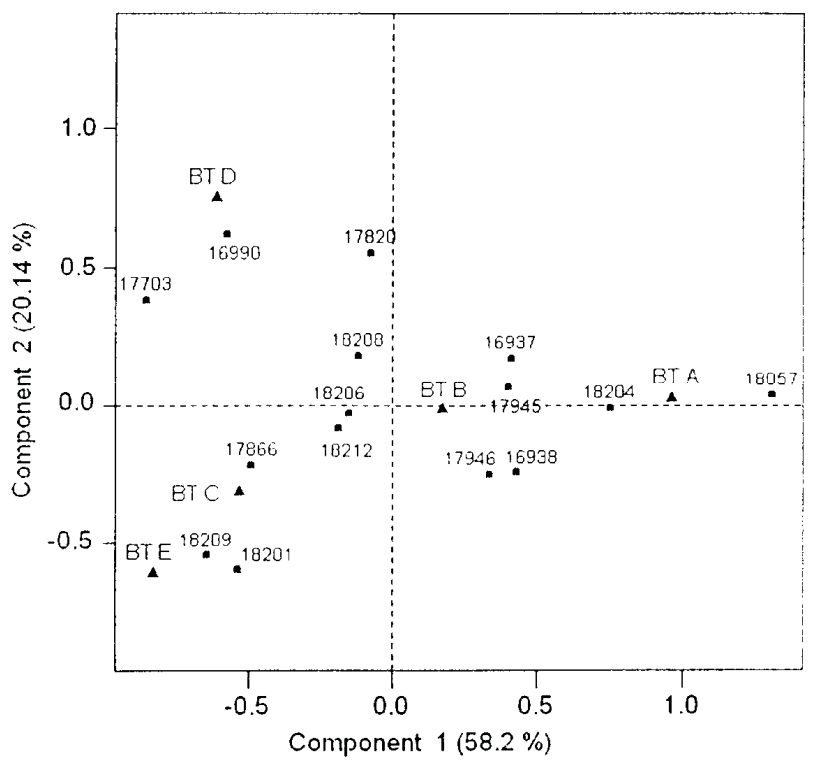

Figure 6. Plotting provenances on crown form with the correspondence analysis 
Likewise, the correspondence analysis in Figure 6 shows that, the crown form categories are also widely spread at great distances, except the category BT C and BT E which are quite close. There is however a trend to cluster. On the bottom right sector, provenance Dimisi Village WP (19201) and Kiriwo/Serisa WP (18209) are in close each other indicating they have similar crown characteristics. Both provenances were associated with category BT E. Furthermore, on the top right, category BT D was associated with the provenance Tully Mission Beach (17703), Derideri R. Morehead (16990), and Aramia R. Balimo WP (17820). BT E and BT $\mathrm{D}$ are described as trees with big crown.

On the bi-plot diagram, the provenances positioned in the left sector posses some superiority on three parameters, i.e. tree height, clear bole height, and tree volume. Thus, the provenances Kini WP, Keru Village WP, Derideri R. Morehead, and Claudia River are potentially more productive than the others. Of these three provenances, two were from PNG and one came from Queensland. This is in accordance with some reports stating that PNG provenances have shown the best performances in Riam Kiwa (Voukko, 1996) and in Birang and Suaran (Sugama and Sutiono, 1999). Nonetheless, provenance Claudia River (Queensland) has also been performing quite well in Riam Kiwa $\left(58 \mathrm{~m}^{3} \mathrm{ha}^{-1} \mathrm{yr}^{-1}\right)$, but not so in Sanga-Sanga East Kalimantan $\left(17.5 \mathrm{~m}^{3} \mathrm{ha}^{-1} \mathrm{yr}^{-1}\right)$. Hence, multi-site trials of $A$. mangium provenances revealed a significant interaction between genotype and environment effects on the total wood production (Awang and Bhuimibhanon, 1993).

Zobel and Talbert (1984) stated that the tree survival and adaptability is often related with provenances (geographic) variation. Genetically controlled provenance (geographic) differences are often large, especially for traits related to adaptability. The best provenance in a given site is the one that most suite the site.

Provenances trials provide some fundamental information in the development of policies or strategies of afforestation. There are obvious advantages if such trials can be initiated well in advance of the time when important investment decisions have to be taken (Burley and Wood, 1976). Many examples of failure, or of partial failure, of afforestation schemes, are recorded where preliminary trials were inadequate. There is no substitute, at present, for adequate provenance trial on typical sites as a basis for large scale afforestation. The characteristics of stem form affect wood quality and values. For solid wood like sawn timber and poles (construction material) the most essential wood properties are technical quality of stems, density, strength and shrinkage (Laurila, 1995). In construction, straight stem or wood is preferred because straightness is related to strength, flexibility and easiness to work. Stem straightness is a big factor affecting harvesting efficiency (Davies, 1970). He also calculated that straightness also increases milling efficiency (5\% reduction in processing time plus $5 \%$ higher conversion rate) which may lead to an increase of mill profits by $15-41 \%$. In some species, most of the value improvement is likely to be due to an improvement in stem straightness (Willan, 1991). 
Based on correspondence analysis on stem form, almost all of the provenances have good stem forms. The best provenances are Kini WP, Olive River, Derideri R. Morehead, Arufi Village, Keru Village WP, Claudia River, Balimo District, Kiriwo/Serisa WP, and Bimadebun Village. Laurila (1995) assessed the straightness of bole with four categories, i.e. straight, slightly crooked, crooked, and extremely crooked. The study states that $A$. mangium provenances are little difference in the straightness of the stem.

\section{Performance of Branching}

Besides straightness, branching system also affects wood quality. In particular, the number of fork significantly affects wood strength of $A$. mangium (Laurila, 1995). According to Laurisen et al. (1995), the best branching system on trees is shown by the branches in the top crown. In addition, the formed branches are relatively small. In the young trees, they are possibly used to self pruning. The poor branching system is signed by the branches that are grown in the lowest stem and big sizes, so it will affect the wood quality.

The good performance in branching system was associated by provenance Keru Village WP, Bimadebun Village, Kiriwo/Serisa WP, Kini WP, Lake Murray, Bensbach Area WP and Claudia River WP. Some studies on branching performance of $A$. mangium provenances were carried out. Hadi (1992) and Nirsatmanto et al. (2004) reported a weak genetic control in the tendency for forking and in straightness of the bole for $A$. mangium provenances. Awang and Bhumibhamon (1993) reported a substantial difference in the forking between $A$. mangium provenances, but an even larger difference between different site locations among the some provenances. Harwood et al. (1993) also found that forking of $A$. mangium is affected more by the environment when the trees are young than the seed origin.

The multi-stemmed habit is an inherent characteristic of $A$. mangium. In operational plantation, the weak genetic control in forking stem must be anticipated by pruning treatment. Beadle et al. (2007) stated that the significant effect of pruning treatment on kink between 3 and $6 \mathrm{~m}$ was possibly associated with the multistemmed controls having generally poorer form.

\section{Performance of Crown}

Wadsworth (1997) stated that the size and the form of tree crown affected the seed production. For seed source establishment, the size and the form of crown must be uniform crown, without heavy branches or double stem (Mulawarman et al., 2003). The big crown describes the capacity to produce the abundant seed. Several provenances are identified as good performance in crown form such as provenance Dimisi Village WP, Kiriwo/Serisa WP, and Derideri R. Morehead. They may produce more seeds compare to others and if the seed has a good viability then will be an advantage for planting program. These selected provenances will 
also be effective to rehabilitate grassland area because they can start closing their crown early, suppressing the growth of grassland.

In summary, for seed production, selection of the best provenances is recommended, not the single best. This is to anticipate the site variation because the single provenance is rarely the best on all sites (Willan, 1991). Five provenances were selected to establish the seed sources for solid wood, i.e. provenance Kini WP, Keru Village WP, Derideri R. Morehead, Kiriwo/Serisa WP, and Claudia River. These provenances showed the best in productivity, stem form performance, branching system, and crown form, as reflected through apparent phenotypic superiority in the trial due to genetic superiority which will be repeated if the selected provenances are planted in the same sites.

\section{CONCLUSION}

Five provenances planted in Parung Panjang are considered prospective for forest plantations producing solid wood in providing raw materials for construction and furniture, vis a vis pulp wood. Those provenances are Kini WP, Keru Village WP, Derideri R. Morehead, Kiriwo/Serisa Village WP, and Claudia River. In general, PNG provenances are consistently better than Queensland (Claudia River). With some treatments (e.g. selective thinning), the proven better provenances can be further established as a seed source supplying forest plantation programs as well as forest farmers.

\section{ACKNOWLEDGEMENT}

Several people provided assistance in this work, in particular Mr. Djoko Iriantono, Dr. Hero Dien P.K., and Mrs. Yulianti. Thanks to Dr. Jeanine Pfeiffer and Mr. Ika Heriansyah for their comments on the manuscript. Thanks also to Muhamad, Adim, and Maman who assisted in data collection.

\section{REFERENCES}

Arisman, H. and E.B. Hardiyanto. 2006. Acacia mangium-a historical perspective on its cultivation. In: K. Potter, A. Rimbawanto, and C. Beadle (Eds.). Heart Rot and Root Rot in Tropical Acacia Plantation. ACIAR Proceeding No. 124. Canberra. Pp. 11-15.

Awang, K. and S. Bhuimibhanon. 1993. Genetics and tree improvement. In: K. Awang and D. Taylor (Eds.). Acacia mangium, Growing and Utilization. Winrock International and the Food and Agriculture Organization of United Nations. Bangkok. Pp. 35-57.

Beadle, C., K. Barry, E.B. Hardiyanto, R.S.B. Irianto, Junarto, C. Mohammed, and A. Rimbawanto. 2007. Effect of pruning Acacia mangium on growth, form, and heart rot. Forest Ecology and Management 238: 261-267. 
Burley, J. and P.J. Wood. 1976. A Manual on Species and Provenance Research with Particular Reference to the Tropics. Tropical Forestry Papers No. 10. Department of Forestry, University of Oxford. 226p.

Davis, L.S. 1970. Economics models for program evaluation. Paper FO-FTB-69 13/2, Second World Consultation on Forest Tree Breeding. FAO Rome. $226 \mathrm{p}$.

Gales, K. 2002. Heart rot in plantation-significance to the wood processing industry. In: K. Barry (Ed.). Heart Rots in Plantation Hardwoods in Indonesia and Australia. ACIAR Technical Report 52. CSIRO publishing, Canberra. Pp. 18-21.

Greenacre, M.J. 1984. Theory and Application of Correspondence Analysis. Academic Press, Inc. London. 364p.

Hadi, A.F. and H. Sa'diyah. 2004. AMMI model for genotype x environment interaction analysis. Jurnal Ilmu Dasar 5: 33-41.

Hadi, T.S. 1992. A study on provenance variation in Acacia mangium Wild. at Riam Kiwa, South Kalimantan, Indonesia. MSc Thesis. Faculty of Agriculture and Forestry, University of Helsinki. 70p.

Hardiyanto, E.B., S.T. Siregar, R. Wahyono, and M. Rokhmin. 2000. The result of Acacia mangium provenance trial at 5.5 years in Selutung. Department of Research and Development, PT. Musi Hutan Persada. Technical Notes 3. 4p.

Harwood, C.E., G. Aplegate, K. Robson, and A.R. Williams. 1993. Early growth of provenances and progenies in Acacia mangium seed production areas in North Queensland, Australia. In: K. Awang and D. Taylor (Eds.). Acacias for Rural, Industrial and Environmental Development. FAO and Winrock International, Bangkok. Pp. 113-122.

Iriantono, D., B.D. Narendra, and U.J. Siregar. 1997. Rak changes, age-age correlations, and increment of 2 years old $A$. mangium provenances trial in Parungpanjang, Bogor, West Java. Seed Technology Bulletin 4: 37-46.

Jollife, I.T. 1986. Principal Component Analysis. Springer-Verlag New York. 271p.

Laurila, R. 1995. Wood properties and utilization potential of eight fast-growing tropical plantation tree species. Journal of Tropical Forest Products 1: 209-221.

Laurisen, E.B., E.D. Kjaer and M. Nissen. 1995. Second evaluation of an international series of Gmelina arborea provenances trials. Danida Forest Seed Centre. Humlebaek-Denmark. 120p.

Lipkovich, I. and E.P. Smith. 2002. Biplot and singular decomposition value macros for excel. Departement of Statistics Virginia Tech. http://ideas.repac.org/a/ jss/jstsof/07105.html. Accessed 29 June 2007. 
Mulawarman, J.M. Roshetko, S.M. Sasongko, and D. Iriantono. 2003. Tree seed management: seed sources, seed collection, and seed handling. TFRI Extension Series No. 152. Winrock International and Word Agroforestry Centre-ICRAF. Bogor. 54p.

Nirsatmanto, A., B. Leksono, S. Kurinobu, and S. Shiraishi. 2004. Realized genetic gaint orserved in second-generation seedling seed orchards of Acacia mangium in South Kalimantan, Indonesia. Journal of Forest Research 8: 127-131.

Otsamo, R. 1996. Integrating indigenous tree species in forest plantations on Imperata cylindrica grasslands-results from Riam Kiwa, South Kalimantan. In: A. Otsamo, J. Kuusipalo, and H. Jaskari (Eds.). Reforestation: Meeting the Future Industrial Wood Demand. Proceedings of a Workshop held in Jakarta, 30 April-1 May 1996. Ministry of Forestry of Indonesia. Pp. 87-95.

Palokangas, E. 1996. Acacia mangium in pulp and paper production. In: A. Otsamo, J. Kuusipalo, and H. Jaskari (Eds.). Reforestation: Meeting the Future Industrial Wood Demand. Proceedings of a Workshop held in Jakarta, 30 April-1 May 1996. Ministry of Forestry of Indonesia. Pp. 24-26.

Raebild, A., L. Graudal, and K.M. Gammanagatti. 2003. Evaluation of a species and provenance trial at B.G. Kere India. Trial No. 15 in the arid zone series. Results and Documentation No. 33. Danida Forest Seed Centre, Humlebaek, Denmark. 38p.

Rimbawanto, A. 2002. Plantation and tree improvement trend in Indonesia. In: K. Barry (Eds.). Heart Rots in Plantation Hardwoods in Indonesia and Australia. ACIAR Technical Report 52 e. CSIRO publishing, Canberra. Pp. 18-21.

Sartono, B. 2003. Theory Model of Double Parameters Analysis. Department of Statistics, Faculty of Nature Science and Math, Bogor Agricultural University.

Sudrajat, D.J., Nurhasybi, and Yulianti. 2006. Parungpanjang Forest Research Station: 1991-2006. Special Publication No. 5. Forest Tree Seed Research Institute. Bogor. 35p.

Sugama and Y. Sutiono. 1999. The growth of Acacia mangium provenance trial at 4 years in PT. Tanjung Redeb Hutani. Proceeding of Annual Meeting of Intregrated Research and Development Network. Yogyakarta.

Suhaendi, H. 1993. Tree improvement of Acacia mangium for industrial forest plantation development in Indonesia. In: K. Awang and D. Taylor (Eds.). Acacias for Rural, Industrial and Environmental Development. FAO and Winrock International, Bangkok. Pp. 113-122.

Turnbull, J.W. 1982. Tropical Acacia in Australia, Indonesia and Papua New Guinea. Report of FAO Consultant. Canberra, Australia. 51p.

Vuokko, R. 1996. Species and provenance selection for plantation forestry on grasslands. In: A. Otsamo, J. Kuusipalo, and H. Jaskari (Eds.). Reforestation: Meeting the Future Industrial Wood Demand. Proceedings of a Workshop 
held in Jakarta, 30 April-1 May 1996. Ministry of Forestry of Indonesia. Pp. 68-80.

Wadsworth, F.H. 1997. Forest production for tropical America. US Department of Agriculture, Forest Service. Washington D.C. Agriculture Handbook 710: 256-258.

Willan, R.L. 1991. Benefit from tree improvement. Lecture Note A-2 Danida Forest Seed Centre. Humlebaek. Denmark. 21p.

Zanzibar, M., Kurniawati, and S.T. Pribadi. 1997. The growth on Acacia mangium provenance trial at 2 years in Sumatra, Kalimantan and Java. Report No. 245. Forest Tree Seed Research Institute. Bogor (Unpublished). 280p.

Zanzibar, M. 2001. Evaluation of Acacia mangium provenance trial in several locations in Indonesia. Annual Research Report. Forest Tree Seed Research Institute, Bogor (Unpublished).

Zobel, B. and J. Talbert. 1984. Applied Forest Tree Improvement. John Wiley and Sons, Inc. llinois. 504p. 